\title{
Bosnia-Herzegovina and the Cultural Memory of Bleiburg
}

\author{
AMRA ČUSTO
}

Institute for the Protection of Cultural-Historical and Natural Heritage, Sarajevo

\begin{abstract}
Summary
This article provides a preliminary overview of the perceptions of Bleiburg among Croats and Bosniaks in Bosnia-Herzegovina, as well as its role in the overall construction of cultural memory in this deeply divided post-Yugoslav state. The author explores how the remembrance of the Second World War in socialist Yugoslavia fragmented and was replaced by new, nationalist narratives among Serbs, Croats, and Bosniaks. The memory of Bleiburg plays a central role in the victimization narrative among Bosnian Croats, and their political leadership has been deeply involved in the commemorative practices related to the events in May 1945. Bosniaks, while primarily focusing on the continuity with the antifascist Partisan tradition, have increasingly opened up the question of communist crimes such as Bleiburg, albeit through the media and memoirs and not yet systematic academic analysis. The article also examines how the Bleiburg narrative is intertwined into the memory of the war in the 1990s, and more broadly how these memory politics are used by various actors in Bosnia-Herzegovina's deeply divided society.

Keywords: Bleiburg, Bosnia-Herzegovina, Second World War, Commemorations, Memory Politics
\end{abstract}

\section{Introduction}

The annual commemorations held in Bleiburg, Austria, have attracted considerable attention in Croatia over the past decade due to the perceptions that it did not properly honor the victims of Yugoslav communism, but rather glorified the defeated fascist Ustaša regime of the Independent State of Croatia (NDH - Nezavisna Država Hrvatska). In the last few years the use of Ustaša symbols and uniforms at the commemoration has even provoked a response from Austrian NGOs and politicians, resulting in a strict regulation by Austrian police, as described in other articles in this special issue. But Bleiburg has received little attention in Bosnia- 
Herzegovina $(\mathrm{BiH})$, even though Bosnian Croat politicians have regularly attended the commemoration and consider the events in May 1945 to have been the greatest tragedy of all Croats, and thus a key element of national identity. This article provides a preliminary overview of the perceptions of Bleiburg among Croats and Bosniaks in Bosnia-Herzegovina, as well as its role in the overall construction of cultural memory in this deeply divided post-Yugoslav state. While systematic work remains to be done into $\mathrm{BiH}$ mnemonic actors, local narratives, and an analysis of the victims of the Partisan crimes, this text seeks to contribute to the transnational approach in the remembrance practices of Bleiburg and the regional significance of this controversial site of memory.

Like any other new government, the socialist government established in Yugoslavia in 1945 attempted to define its relationship to history by creating a politics of memory and identity. The new Yugoslav regime constructed this proclaimed collective memory around the People's Liberation War and the socialist revolution. Using a narrative based on selected events from the period of 1941-1945, the government painted a relatively simplistic picture of the Second World War with heroic Partisans and murderous fascist collaborators (Bergholz, 2010; Karačić, Banjeglav, and Govedarica, 2012). There were exceptions, and as the regime liberalized, nuances increasingly emerged not only in the historiography but also in popular culture, especially in Partisan films that challenged the black and white interpretations of the war (Jakiša and Gilić, 2015). Certain topics, such as Jasenovac or Bleiburg, remained under the watchful eye of the Party, and challenging the official narrative could result in a loss of a position or a ban on publishing. The history, memory, and ideology of the new system were not only focused on the labor movement and the struggle against the so-called non-national regimes, but also the well-known battles and offensives of the Partisans, People's Heroes, prominent communists, as well as the history of the Party led by Tito. By simplifying the interpretation of the war, and generating a socially desirable narrative, the governing elites demonstrated their dominance by constructing the past in a way that would help maintain the unity of the Yugoslav community, clearly labelling all participants of the Second World War as either good or bad, as the victors or the defeated. For those who did not fit into this set framework, there was no place in this past (Sundhaussen, 2006: 246).

To build the events into the cultural memory, a variety of means and media were used: educational television programs, street names and films, and many monuments that served as sites of commemorations and sites of memory (Nora, 1997). For almost fifty years, Yugoslav politics of memory suffered from a chronic selectivity in order to prevent any shadow of a doubt that could undermine the image of the revolutionary and liberal tradition of the Yugoslav nations. This meant that the official narratives of the war focused on the shared struggle against foreign occupiers and domestic collaborators rather than the victims of interethnic violence and 
especially Partisan crimes at the end of the war (Jambrešić-Kirin, 2006). Different memories, those that were complex, overly traumatic, and dealt with victims of the defeated side, had no place in official politics. Left aside, they were archived in family histories and memories.

Due to its multinational constitution and the constructed narrative on "brotherhood and unity", and as the central stage of the antifascist struggle, well-known battles, and the revolution, Bosnia-Herzegovina held an important place in socialist Yugoslavia and carried specific weight in the country's overall cultural memory. Across Yugoslavia, numerous sites of memory were built, envisaged to stand as eternal testimony to antifascism and the struggle of all Yugoslav nations. These sites were massively visited not only during celebrations of anniversaries and important dates, but were also mandatory destinations for school trips and other organized visits. Even in the 1980s, during the severe economic and political crisis when national separatism and the breakup process of the country had already become evident, the official government structures in Bosnia-Herzegovina were still insistent about maintaining what used to be, at least in theory, a unified Yugoslav identity. The BiH authorities continued building monuments to the People's Liberation War, including large memorial parks such as the Vraca Memorial Park in Sarajevo, and supported academic conferences on nurturing and developing the traditions of the People's Liberation War and the socialist revolution. They believed that in the context of the prevailing Yugoslav political circumstances and complex national relations, the maintaining of such politics of memory would keep its integrating influence within $\mathrm{BiH}$ society. ${ }^{1}$

After the victory over fascism, the monopoly of power held by the Yugoslav political elite was institutionalized in the Communist Party of Yugoslavia (KPJ Komunistička partija Jugoslavije). The KPJ legitimated the political system by constructing a cultural memory that celebrated the Partisan struggle as glorious and heroic, spurring a revolution and building a new Yugoslavia. In this context, the year 1945 had great significance in the chronology of state formation. This year was not only celebrated as victorious, but also it was presented as crucial in the creation of a just, socialist society that was based upon entirely new social values and identity. Thus, one could not expect that the image of victory and the new socialist society would be allowed to be complicated with events such as Partisan retaliation, revenge, and the killings of enemy combatants and their family members who surrendered at Bleiburg - all of which was also part of 1945.

In Bosnia-Herzegovina, the first signs of attempts to openly deal with the memories of the events and different experiences of the Second World War appeared

1 “Budućnost na revolucionarnim tradicijama”, Oslobođenje, 4 February 1981. 
in the late 1980s and early 1990s, at the time when the Yugoslav system was falling apart. This was the time when new, mainly nationalist, parties emerged and dehomogenized the $\mathrm{BiH}$ political scene. To a large extent they used strategies such as evoking previously suppressed memories and introducing previously taboo history topics, including myths about victimization, memories of mass killings of one's own ethnic group, and organized religious rituals. ${ }^{2}$ However, the looming war of the 1990s and the new sufferings in Bosnia-Herzegovina that ensued brought about new memories and the construction of new memory politics that rested on, and became entwined with, the events from the Second World War. The crucial event and the starting point of the new history and today's cultural memory in Bosnia-Herzegovina was the war of the 1990s. But there are also other themes from earlier historic periods which entered into the public discourse, opening up a wide space for a whole series of different memories, particularly for those people who were not on the victorious side in the Second World War.

One of the key taboo topics in Yugoslavia was related to the Bleiburg massacres, when Yugoslav Partisans captured and executed a number of defeated enemy combatants, among them members of the Croatian Armed Forces (the army of the $\mathrm{NDH}$ ) and the civilians fleeing into Austria. Although decades have passed after the tragic events in Bleiburg, this site and the related incidents have been the subject of considerable historical manipulation (see the other articles in this special issue) and interpretations, particularly during the time of the annual May commemorations. While the majority of recent research has focused on the perception of Bleiburg in Croatia, this article argues that it is also a sensitive moment in the recent history of Bosnia-Herzegovina. More and more frequently, the public space in Bosnia-Herzegovina is filled with opinions and interpretations burdened with current political dynamics and inter-ethnic relations that produce different, often opposing cultural memories on Bleiburg. In the public discourse, discussions about Bleiburg are a reflection of the overall position towards the Second World War, fascism and antifascism, communism and anticommunism, the Partisans, Ustaše and Četniks, as well as a reflection of the contemporary three-fold political and national relations among the Croats, Bosniaks, and Serbs in Bosnia-Herzegovina. Therefore, the aim of this article is to provide an overview of BiH cultural memory on Bleiburg that is primarily viewed from the perspective of one's own national community, each of which is, in turn, internally divided between the so-called leftist and rightist positions.

2 One of the events from the end of the 1980s that received a lot of media attention at the time was the carrying of the remains of Prince Lazar, whose aim was to raise Serbian national awareness throughout Yugoslavia. See Milan Damjanović, "Povratak Kneza Lazara”, Nin, Beograd, 17 September 1989. 


\section{Bleiburg, the Suffering of the Past and the Present}

When the long-buried historical story about the tragic events at Bleiburg first came out in the open in Croatia in the 1990s, a one-sided collective narrative was constructed about the site of great Croatian suffering and communist crimes, without any deliberation over who the actual victims were. The Croats in Bosnia-Herzegovina not only accepted this victimization narrative of Bleiburg, but actually contributed to it (Pavlaković, 2009). One of the phases in the development of Bleiburg commemorations and their acceptance in Bosnia-Herzegovina was a public inquiry about communist crimes and the organization of different commemorative practices related to Bleiburg. The first commemorations of Bleiburg were organized during the destruction and killings of the 1990s, when the war was still raging across Bosnia-Herzegovina. There are records of commemorations that marked the fiftieth anniversary of Bleiburg atrocities organized at Sarajevo churches in 1995, when Mass services were held for Bleiburg victims. ${ }^{3}$ In that same year, when Sarajevo was still under siege, the executive council of the Croatian Democratic Union (HDZ) held a commemoration for all victims of Bleiburg and the Way of the Cross at Camera Theatre 55. In the public sphere, this commemoration opened a number of questions regarding Bleiburg from the perspective of Bosnia-Herzegovina, which not only relate to the number of victims and who exactly they were, but also to their nationality: were the victims only Catholic Croats, or also Croat Muslims, etc.? The participation of the Ambassador of the Republic of Croatia to Bosnia-Herzegovina, Zdravko Sančević, in the organizing committee of the commemoration spoke about Croatia's engagement in the synchronized, national action whose aim was to establish a new politics of memory in relation to Bleiburg. Other members of this committee at the time were Muhamed Zulić, an HDZ member of the Croatian parliament and at one time minister without portfolio in the Croatian government, who also acted as a representative of the Croatian parliament at Bleiburg commemorations in 1993, and Nijaz Baltak Daidža, a.k.a. Mate Šarlija, a major-general of the Croatian Army. They, in a way, continued the practice of Muslims who declared their ethnicity as Croatian, similar to some of the first members of the Bleiburg Honorary Guard (Omer Vrabac, Adem Delić, Sulejman Hrle, Ibrahim Pjanić, and others), who were close to Croatian diaspora and active in their support to the establishment of Bleiburg commemorations. ${ }^{4}$ Through their actions, they presented the issue of Bleiburg atrocities from the Croatian perspective and the perspective of

3 “U Sarajevu služene svete mise za bleiburške žrtve", Vjesnik, 15 May 1995.

4 Other members of the HDZ Bleiburg commemoration executive committee were Vice Vukojević, Krešimir Alerić, Ivan Butković, Stjepan Džalto, Ćiro Grubišić, and Friar Viktor Nuić. See Edina Kamenica, “Enigma Bleiburg u Sarajevu”, Oslobođenje, 15 May 1995. 
the victims who were ethnic Croats, which implicitly included those Croats among them who were Muslims by religious denomination.

Over time, from the mid-1990s onwards, the number of participants at the Bleiburg commemorations increased, including a significant number of Bosnian Croats. This confirms that Bleiburg is a very painful issue representing national (Croatian) trauma from the Second World War. Thus Bosnian Croats actively became involved in the ceremonial commemorations at Bleiburg, which are always held in May and are led by the HDZ and war veterans' associations from the 1990s. Typically, the anniversary celebrations are preceded by public invitations to Bleiburg with organized transport for all attendants, while street banners in cities like Mostar carry slogans such as "They dreamt of their Homeland- Bleiburg 1945-2015" and "Invisible for 45 years; abandoned for 25 years - Bleiburg", 5 thus inspiring collective memory. This indicates that Bleiburg has transitioned from the socialist time of oblivion to a paradigm of a mythical place, which testifies to the difficult twentieth century. The public manifestation of the collective memory currently constructed around this site of memory illustrates how important the role and the function of common rituals are in the expression of national unity (Assmann, 2005). The success of this unified action aimed at creating a monoethnic cultural memory that tells one side of the story, one in which Croats were killed regardless of their role in the war, is also reflected in the fact that the Bleiburg Honorary Guard cosponsors commemorations held in various cantons in Bosnia-Herzegovina, such as the West Herzegovina Canton, where "a great number of families went through that bitter experience". ${ }^{6}$

The first attempts, initiated by the HDZ-BH, to establish a collaboration between Croatia and Bosnia-Herzegovina at the highest, representative level, and form a parliamentary delegation which would act jointly at official Bleiburg commemorations started in the first decade of the 21 st century, but this collaboration has only recently been achieved. ${ }^{7}$ The seventieth anniversary commemoration in 2015 was the first one officially sponsored not only by the President of the Republic of Croatia, Kolinda Grabar-Kitarović, but also by the Croat member of the Presidency

5 “Mostar: 45 godina vas skrivaju, 25 godina vas zaboravljaju, Bleiburg”, 15 May 2016, online at https:/www.hercegovina.info/vijesti/hercegovina/mostar-hercegovina/mostar-45-godina-vasskrivaju-25-godina-vas-zaboravljaju-107384; and "Mostar: O domovini san su snili... - Bleiburg 1945-2015", 20 May 2015, online at https://www.hercegovina.info/vijesti/hercegovina/mostarhercegovina/mostar-o-domovini-san-su-snili-bleiburg-1945-2015-91809.

6 “Županijska Skupština pokrovitelj komemoracije na Bleiburgu”, 27 April 2012, online at http://ljubuski.net/7888-zupanijska-skupstina-pokrovitelj-komemoracije-na-bleiburgu.

7 “I Tita ‘izručiti’ Hagu”, Nezavisne novine, 30 April 2004. 
of Bosnia-Herzegovina, Dragan Čović. ${ }^{8}$ According to the official statements issued by the Croatian National Assembly (HNS - Hrvatski nacionalni sabor) in BosniaHerzegovina, Dragan Čović's participation at Bleiburg as the president of the HNS was seen as promoting Croatian national goals through the action of "all Croats". 9 The speeches given by representatives of the Croatian political elite from BosniaHerzegovina reflect the general atmosphere at the commemoration, whose aim is to inspire the participants by stressing the importance of Bleiburg as a symbol of the Croatian suffering, but at the same time, a symbol of unity and "a site of the cult and piety". ${ }^{10}$ This unified official performance within the Croatian national community practically demonstrates "the adjustment of all of its institutions towards the construction of a unanimous memory" (Đerić, 2009: 84). The Catholic Church is an important segment in consolidating this unity. Its two episcopal conferences, the Croatian Bishops' Conference and the Bishops' Conference of Bosnia-Herzegovina, by acting and speaking together at commemorations and promoting the same religious content, contribute to the sense of national belonging as well as emotional and religious connection among all participants in the ritual. Even in socialist Yugoslavia, there were officials of the Catholic Church whose role was to guard the national memory of Bleiburg. According to a joint press release by the two conferences in 2006, these guardians are regarded with respect and gratitude for not allowing this memory to wane at the times of hardship before the 1990s. ${ }^{11}$

It is true that Bleiburg was a site where in the chaotic final days of the war, during the final showdown between the victors and the defeated Axis collaborators, a certain number of soldiers and civilians were killed without any organized trial, and that the silence about it was an example of a taboo topic. The fate of those "on the other side" was spoken about only within families as part of their personal memories, experiences, and limited knowledge about the destinies of family members who never returned. The Croatian population in Bosnia-Herzegovina, especially

8 "Predsjednik HNS Dragan Čović i predsjednica RH Kolinda Grabar Kitarović pokrovitelji komemoracije na Bleiburgu", 16 May 2015, online at http://hnsbih.org/predsjednik-hns-a-dr-dragan-covic-i-predsjednica-rh-kolinda-grabar-kitarovic-pokrovitelji-komemoracije-na-bleibur$\mathrm{gu} /$.

9 The HNS considers itself the umbrella political organization of Bosnian Croats, which, in the words of its founders, is a "collection of everything about Bosnian Croats that has political value". See "Hrvati u BiH danas žive Bleiburg, nema predaje", 15 May 2011, online at http:// www.vecernji.ba/hrvati-u-bih-danas-zive-bleiburg-nema-predaje.

${ }^{10}$ Dragan Čović in his speech at the seventieth anniversary of Bleiburg in 2015, see the FRAMNAT database at http://framnat.eu/bleiburg-transkripti/\#tab-id-4.

${ }^{11}$ An announcement from the joint session of the members of the Croatian Bishops' Conference and the Bishops' Conference of Bosnia-Herzegovina, 30 March 2006, online at http:// www.bkbih.ba/info.php?id=685. 
those living in Western Herzegovina, felt particularly connected to this suppressed history. Namely, the region of Western Herzegovina used to provoke a series of controversies in the public discourse of socialist Yugoslavia. War atrocities, internecine killings, mass violence against Serb civilians in Herzegovina in 1941, and the role of the Catholic Church in the Second World War - all of this created an image of Western Herzegovina, even stigmatized it, as an Ustaša region, where antifascist Partisan forces were never able to mobilize a great number of people into their army. This territory also included the towns of Čitluk, Ljubuški, Široki Brijeg, and other localities whose population also took part in Bleiburg and the Way of the Cross events in 1945. In the formative narrative of socialist Yugoslavia, the tragedy of the Croats from Western Herzegovina during the war was mainly described as a result of manipulation by the Ustaša government and certain representatives of the Catholic Church, which eventually resulted in the justified execution of collaborators (Galić, 2005). However, today the narrative is different and the perception of the cultural memory is entirely reversed. The accumulated painful history and suffering are largely presented as a consequence of communist revolutionary violence in the last year of the war. Considering that the number of crimes committed by communists in Bosnia-Herzegovina in 1945 was never really investigated or adequately established, this created considerable room for manipulation. In this sense, the case of Western Herzegovina is an example of a constant shifting relationship to history, where conflicting narratives are offered to the public depending on the political context. This political context then changes and shapes the dominant cultural memory, while simultaneously political and social actors contribute to a simplified image of the Second World War devoid of any critical interpretations. So, in the same way the Yugoslav political elite ignored Bleiburg and kept it secret for the sake of maintaining the image of the united brotherhood of the Yugoslav nations, avoiding dealing with the past, the new cultural memory is now being built around a position narrowed down to one ethnocentric perspective and its claim to the truth.

With the topic of communist crimes and narratives about their killing sites out in the open, a new commemoration was inaugurated at Radimlja near Stolac and held regularly since 2005. This site was characterized as "Bleiburg's younger sister" ${ }^{12}$ due to the extent of the crimes and alleged number of victims (around 10,000) who were killed by the Partisans in the hills, pits, and other places across Radimlja. ${ }^{13}$ Another example of this new practice was the construction of a monu-

12 "U očekivanju sutrašnjeg skupa na Radimlji - Vidoštačka kraljica pjesnika Pere Pavlovića", 10 May 2005, online at http://rb-donjahercegovina.ba/tekstovi/u-ocekivanju-sutrasnjeg-skupana-radimlji-vidostacka-kraljica-pjesnika-pere-pavlovica.

${ }^{13}$ Commemoration at Radimlja on 25 May 2016, online at http.//www.ktabkbih.net/info. asp?id $=64578$. 
ment to Bleiburg victims at the same site. While the erection of this monument provoked a reaction by some media in Sarajevo, this reaction, interestingly, was not triggered by different interpretations of the events in the Way of the Cross and the related dilemmas and issues, but rather by the fact that the monument was illegally erected near the national monument of Radimlja necropolis (dating back to the medieval times). The criticism was also spurred by political disputes between the local branches of the HDZ and the Party of Democratic Action (SDA). Besides the illegal erection, another issue was the financing of the monument. The president of the Stolac Youth Forum, Nerin Dizdar, claimed that it was probably the Catholic Church that financed the erection of the monument in cooperation with the Stolac branch of HDZ. He also claimed that "Stolac was related to Bleiburg just as much as BiH was related to the EU". ${ }^{14}$ The commemorative ceremony at the monument to Bleiburg victims in Stolac, along with the Holy Mass for all Catholic Croats killed in the Second World War, is held in May as part of the "Stolac Cultural Spring" manifestation. This, in the words of Todor Kuljić, symbolically encourages "integration through a chosen date" (2005: 30-34), which in this case is associated with the date of the memorial commemoration held every year in Bleiburg, Austria. In this way, the monument at Radimlja becomes not only a new site of memory dedicated to the fallen Croats from the region, but also a site where simultaneously the new relationship to history, fascism, and the Second World War is expressed. This new perspective on the antifascist legacy can also be noticed in the practice of building monuments to the fallen soldiers in the war of the 1990s, whose names are listed next to the names of the people killed in the Second World War, regardless of whether they belonged to the Ustaša or Partisan forces, whether they were civilians, or those who were killed as victims of the so-called communist terror. This helps shape the view that it does not matter how they died and under which circumstances because they are all "our" victims. This method of dealing with the antifascist memory and the nationalization of victims can be found in other parts of Bosnia-Herzegovina, painting an entirely different picture of the past and the Second World War. This new representation is further reinforced through street names, the building of monuments to post-war victims (victims of communist terror), as well as blurring the events of the distant and recent past. The political elite has tried to do this through analogies and creating links between the war victims of the 1990s and the Bleiburg victims by organizing memorial ceremonies to honor the fallen members of the Croatian Defense Council (HVO) and commemorate other events from the war (1992-1995). Integrating the content of the Way of the Cross in the newly established ceremonies symbolizes a politics of memory which places focus on the nationality of the victims,

${ }^{14}$ Asaf Bećirović, "Vlasti ne reaguju na gradnju spomenika žrtvama Blajburga", Oslobođenje, 6 May 2005. 
who fell in the name and defense of Croatian interests. For example, a manifestation organized in Široki Brijeg, Memories of May, honors the memory of people killed in the war of the 1990s, but also marks the memory of the former minister of defense of the Republic of Croatia, Gojko Šušak, and ends with an organized group trip to Bleiburg and participation in the commemoration. ${ }^{15}$ The relationship between the Homeland War and Bleiburg is built around the idea that the struggle and the execution of Croats in 1945 and the 1990s should not be forgotten, which helps create a unified and compact narrative about the national history and its thorny path and evolution. Therefore, across Bosnia-Herzegovina, participation in the Bleiburg commemorations are most frequently organized by local HDZ officials in cooperation with various Homeland War associations and local veteran societies. ${ }^{16}$

Today, the society in Bosnia-Herzegovina is divided by ethnicity, and this is reflected in what we find in different politics of memory - they are ethnocentric, insensitive to other politics, and dominated by the content that focuses on injustice and pain inflicted exclusively onto them by others. The interpretation of Bleiburg and the Way of the Cross is therefore easy to fit into such matrix of memory, and it does not only connect the events of 1945 and the 1990s, but also links to the current political issues and circumstances, such as the issue of the status of Bosnian Croats within Bosnia-Herzegovina. Namely, as the political discussions and demands of constitutional reform in Bosnia-Herzegovina are in full swing, HDZ politicians resort to using symbols of Bleiburg when making public statements about inequality and the disadvantaged position of Bosnian Croats today. For example, in his speech at the Bleiburg commemoration in 2011, the chairman of the General Secretariat of the Croatian National Assembly, Božo Ljubić, conveyed a clear message that Bleiburg is what Bosnian Croats live today as victims of the political ethnocide conducted by "those who haven't renounced the ideological and every other legacy of those who committed the genocide of 1945. Unfortunately, their actions are supported by some who call themselves Croats." He also stated that "the leaders of the politics of suppression of Bosnian Croats are not as powerful as their predecessors from 1945, while Croats today are not as powerless". ${ }^{17}$ In this political speech, Bleiburg was used as a metaphor for the disadvantaged position of Bosnian Croats.

15 “Svibanjska sjećanja 2016: Obilježava se 18. godišnjica smrti Gojka Šuška”, 3 May 2016, online at http://www.pogled.ba/clanak/svibanjska-sjecanja-2016-obiljezava-se-18-godisnjicasmrti-gojka-suska/87494.

16 “Općina Tomislavgrad organizira put na komemoraciju u Bleiburg", 4 May 2016, online at http://www.hercegovina.info/vijesti/hercegovina/tomislavgrad/opcina-tomislavgrad-organiziraput-na komemoraciju-u-bleiburgu-106858.

17 "Hrvati u BiH danas žive Bleiburg, nema predaje", 15 May 2011, online at http://www. vecernji.ba/hrvati-u-bih-danas-zive-bleiburg-nema-predaje. 
At the same time, this illustrates how a mindset can be formed through a perspective of the victim using tragic past experiences that expose the Partisan movement and drawing on the injustice that was inflicted on Croats in the past, and which continues until today. This speech can also be examined as an attempt of putting an end to the ideology of socialist Yugoslavia and condemning the lack of unity within the Croatian national corpus in Bosnia-Herzegovina.

This position did not arouse much interest among Bosnian and Serbian political elites and their representatives on the $\mathrm{BiH}$ political scene, nor was there any reaction from those who represented left-wing politics and parties. But there was one reaction, that of Friar Petar Jeleč, ${ }^{18}$ which showed that there was no general consensus among Croats about the cultural memory of Bleiburg. Namely, Friar Petar Jeleč described the speech of Božo Ljubić as one of the "most unethical statements made in this region over the past few decades; a statement that would astound any person who truly cares about victims". ${ }^{19}$

As the other articles in this special issue show, the Bleiburg commemorations are very politicized and dominated by the victimization narrative of the execution and massacres of Croats by Tito's Partisans. Also, they demonstrate a frequent tendency to equalize fascism and communism, show lack of any critical approach to investigating whether there were any war crime perpetrators among the innocent victims of Bleiburg and the Way of the Cross, support the usage of Ustaša iconography by commemoration participants, and relativize the NDH (Independent State of Croatia) regime, proclaiming only one truth about a place where "the greatest sons of the nation" died. ${ }^{20}$ But in Bosnia-Herzegovina, there is another meaning added to it, evident in using Bleiburg as a weapon in the contemporary political and national conflicts and positioning. The correlation between 1945, the 1990s, and the current time and the situation in some parts of Bosnia-Herzegovina was also drawn by Bishop Franjo Komarica, head of the Diocese of Banja Luka, in his response to the criticism over his participation at the Bleiburg commemoration. Alluding to the events from the 1990s, and the execution and prosecution of the non-Serbian population in Banja Luka, he said: "Come to Banja Luka and see for yourselves; this is where Bleiburg is. Where are the people of Banja Luka? Why were they killed?

18 Friar Petar Jeleč is a member of the Franciscan Province of Bosna Srebrena and is a theologian and historian teaching at the Franciscan Faculty of Philosophy and Theology in Sarajevo.

19 "Hrvati u BiH: Žrtve Bleiburga uspoređene sa foteljom u vlasti koju je izgubio Dragan Čović”, 16 May 2011, online at http://24sata.info/kolumne/fatamorgana763597-hrvati-u-bihzrtve.

20 "Dragan Čović na blajburškoj komemoraciji: Politički položaj Hrvata u BiH je težak i nepravedan”, 18 May 2014, online at http://www.oslobodjenje.ba/vijesti/region/dragan-covic-nablajburskoj-komemoraciji-politicki-polozaj-hrvata-u-bih-je-tezak-i-nepravedan-/107816. 
Why were they deprived of their right to identity? They don't have a right to their birth place. For me, that's Bleiburg." 21 The fact that Bishop Komarica attended the commemoration in Bleiburg and then "defended" himself about it evoked memories of 1945, and provoked a response of the other side: officials from Republika Srpska, in particular President Milorad Dodik, who in their fervent reaction used the antipode of Bleiburg, the Jasenovac concentration camp, and recalled the Serbian victims of the Second World War.

Milorad Dodik stated that by comparing Banja Luka to Bleiburg, Bishop Komarica offended not only the living population of Banja Luka and the entire Republika Srpska, but also showed disrespect towards all victims killed at various execution sites in the Second World War. At one of his frequent press conferences he sent the following message to Komarica:

I am sure that you are well aware that some of the Bleiburg victims bore responsibility for the executions of our people at Potkozarje, Banja Luka, and Donja Gradina, but that none of our victims were responsible for the death of the people that you held a Mass for in Bleiburg. Therefore, to compare Banja Luka to Bleiburg is frightening, to say the least. ${ }^{22}$

This discussion was then joined by Bakir Izetbegović, the Bosniak member of the Presidency of Bosnia-Herzegovina and the president of the SDA, who added the third national voice to this dispute. He stood by the bishop's side, emphasizing that any attacks on Bishop Komarica were unacceptable and unjustified because he only wanted to draw attention to the non-Serbian victims of Banja Luka that had been killed in the 1990 s war. $^{23}$

Therefore, the questions of crimes, ethnic cleansing, traumatic memories, and unresolved issues from the Second World War are interwoven with the disturbing experiences from the war of the 1990s and fused together in the public discourse of Bosnia-Herzegovina today. At the same time, the victims are used as a powerful weapon for collective bonding and homogenization, while empathy is shown only for one's "own" victims and never for the victims of "the others".

21 “Biskup Komarica: Banja Luka je za mene Bleiburg”, 17 May 2016, online at http://balkans. aljazeera.net/vijesti/biskup-komarica-banja-luka-je-za-mene-bleiburg.

22 “Dodik 'napao' biskupa Komaricu: Strašno je usporediti Bleiburg i Banja Luku”, 18 May 2016, online at http://prvi.tv/vijesti/bih/dodik-napao-biskupa-komaricu-strasno-je-usporeditibleiburg-i-banja-luku/67455.

23 "Bakir Izetbegović: Bošnjaci i Hrvati sustavno su tjerani, Banja Luka nije bila pod opsadom, niti je tamo bilo ratnih sukoba, a to se ipak dogodilo", 29 May 2016, online at http://hr.n1 info. com/a127196/Svijet/Regija/Izetbegovic-brani-Komaricu-Hrvati-i-Bosnjaci-protjerani-su-izBanje-Luke.html. 


\section{Bleiburg and Bosniaks}

The dominant perception of the wider public in Bosnia-Herzegovina was that Bleiburg was a "Croatian issue", and only recently has this topic started drawing the attention of Bosniaks. How come that for such a long time Bosniaks showed no interest in Bleiburg despite the fact that there was a significant number of them who were also connected to these tragic events? Was it due to the enormous impact that the events of 1992-1995 have had on today's cultural memory of Bosniaks, casting a shadow over the memory of Bleiburg, or, have the revisionism and new perspectives on the Second World War simply never developed to the extent and at the rate as they have among Serbs and Croats? (Kamberović, 2006: 33). Or is it the case that Bosniaks were simply caught unaware by these issues and that's why they are lagging behind?

Thus far, not a single Bosnian historian has offered a more serious critical examination of Bleiburg, so this obvious void has been filled with memoirs and journalistic texts. The publicist Nihad Halilbegović wrote about fallen Bosniaks, especially those from the region of Gračanica, who are collectively remembered as "those who have departed" (oni koji su odstupili) (Hamzić, 2006: 101-111). In an atmosphere where historical topics are exploited as an instrument in daily political antagonisms, with a scarce memoir literature (Sulejmanpašić, 2006) and an absence of sufficient historical research, the media has taken the leading role in discussing Bleiburg. Ideologically, it is characterized by an ambivalent attitude towards communism and antifascism within the Bosniak community in both Croatia and BosniaHerzegovina.

Bosniak participation in the annual Bleiburg commemorations is manifested through the official participation of the representatives of the Mešihat (Islamic Community) of Croatia. In their public speeches, the representatives always refer to the fallen Muslim victims in 1945 as well as their status in the collective memory, in which they were neither remembered nor acknowledged. In other words, the Bleiburg Muslim victims were "renounced by some and obscured by others". ${ }^{24}$ This reflection on the status of Bosniak victims does not refer to the socialist times, when officially it was not even possible to commemorate them, but rather to the new collective cultural memory where there is not much space for them. They are not "treated" in any way; they are simply forgotten. On the other hand, Bosniaks are not specifically acknowledged because Bleiburg commemorations have a distinctly nationalist, Croatian content, where Bosniaks do not really fit. Another is-

${ }^{24}$ From the speech by Idriz ef. Bešić, representative of the Islamic Community of Croatia, at the Bleiburg commemoration in 2012. Dino Sardi, "Bratstvo i jedinstvo na Bleiburgu", 19 May 2012, online at http://www.bosnjaci.net/prilog.php?pid=45792. 
sue why Bosniaks would not be likely to link their identity to the Bleiburg events is the fact that in the NDH the regime considered them to be Croats of Islamic faith (Hasanbegović, 2007). The inscription on the monument on Bleiburg field, "For the honor and glory of the fallen Croatian army - May 1945", explicitly states the nationality of those being remembered. However, the Islamic symbols of the moon and star are located along with the Croatian checkerboard (šahovnica) and the cross, referring to and commemorating Muslim members of the NDH armed forces killed in 1945.

At Bleiburg, the representatives of the Islamic Community of Croatia give speeches in which they appeal to the Bosniak community for the need to unite and develop a patriotic awareness using the symbolism of Bleiburg. In their public appearances they also draw correlations between the killings of Bosniaks in 1945 and the massacre of Srebrenica in 1995, suggesting that the same model was used in both crimes, thus implying there was a relationship between the Serbian armed forces and the crimes committed in 1992-1995 and the communist movement and their repression in $1945 .{ }^{25}$ However, the appeal for unity has born no fruit. On the contrary, until recently there was even criticism over Bosniak participation in Bleiburg commemorations coming from those who actually promote Bosniak national politics and culture. From their perspective, Bleiburg is a site of gathering and public promotion of Croatian right-wing politics, where participating Bosniaks only discredit themselves by supporting Ustaša ideology, while their speeches are often interpreted with irony as a manifestation of "brotherhood and unity" at Bleiburg. ${ }^{26}$

Such a position fits well with the Bosniak antifascist culture of memory of the Second World War, or rather the absence of a more explicit Bosniak anti-communist position. Until recently, the prevalent narrative about the Second World War among Bosniaks was the antifascist one, despite the traumatic experiences and killings of Bosniaks immediately after the liberation in 1945 (Hoare, 2006; Hurem, 2016). The Partisans especially targeted those individuals with bourgeois backgrounds and from intellectual circles, including members of the ulema (scholars of Islam) and those who did not accept the new Yugoslav state and its ideology. The survival of the antifascist narrative lies in the fact that Bosniaks received national recognition and emancipation in socialist Yugoslavia. The anticommunist discourse was not prevalent even in the 1990 s during and after the latest war. Only recently has the media included a new nationalist rhetoric calling for the accountability of the mem-

${ }^{25}$ Idriz ef. Bešić, speech at Bleiburg, 12 May 2012, online at https://www.youtube.com/

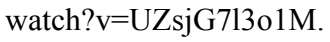

${ }^{26}$ Dino Sardi, "Bratstvo i jedinstvo na Bleiburgu", 19 May 2012, online at http://www.bosnjaci. net/prilog.php?pid=45792. 
bers of the so-called Bosniak Left, who have been reproached by some Bosniak national circles for never showing any intention to deal with communist crimes. Journalists raised questions about the concealed historical truth of the murder of some 20,000 to 65,000 Muslims from $\mathrm{BiH}$, mostly of Bosniak nationality, committed by the communist regime during and particularly after the Second World War. ${ }^{27}$ In this context, the topic of Bleiburg increases in importance, and there has been criticism that while across the region there are investigations by other countries of the mass murders committed by Yugoslav communists against their nationals, "in the historiography of Bosnia-Herzegovina, there is not a single completed study of this kind". ${ }^{28}$ Discussions about the killings of Bosniaks at Bleiburg are disseminated by some weekly papers and online media, which position themselves as promoters of Bosniak national identity. ${ }^{29}$ They also write about the killings of the Islamic ule$m a$, which, in their opinion, received the worst possible treatment in the anti-Islamic ideology of the communist government. Namely, the communist government grouped them together with the fascist bloc and took their revenge on them not only in 1945, but also in the trials against the Muslim Youth and Muslim intellectuals from 1946 to 1949 , and later in the prosecutions that were held against them in $1983 .{ }^{30}$

27 Nedžad Latić, "Njihov obračun sa nama. Bošnjačka ljevica možda i zna šta bi sa Bosnom, ali ne zna šta bi sa islamom”, 19 November 2016, online at http://thebosniatimes.ba/clanak/6361.

28 Ibid.

29 These include the weekly Stav, and the online portals bosnae.info and bosna Press.

30 The naming of a school in Sarajevo after Mustafa Busuladžić, a writer, member of the Muslim Youth, and an anticommunist shot by the Partisans in 1945, raised disputes between the so-called left and right about communist crimes. The naming particularly provoked a reaction from some intellectuals and members of leftist political parties who argued that Busuladžić's ideas were very close to fascism, citing some of his work. For example, the political scientist and philosopher Tarik Haveric criticized this rehabilitation, stating that "it would be hard to find in our literary works warmer words for the New Order that will come into being when Mein Kampf defeats Das Kapital than in M. Busuladžić's writings", 10 November 2016, online at http://www.6yka. com/novost/116772. See also Haverić, 2016. Historian Husnija Kamberović has also reacted in the press regarding the partial rehabilitation of individuals sentenced in post-war trials: "We need to know exactly what we want and why we want to rehabilitate some people, and others not. Why do we want to rehabilitate Mustafa Busuladžić, who was tried in 1945 and sentenced to death by firing squad, but not others, some of whom were tried in the same courts as Busuladžić and others who were liquidated without any trials during the war or post-war period? In Serbia, for example, when they are rehabilitating Mihailović, they claim they are not really rehabilitating him but rather just proving that the trial was conducted improperly. I ask you how consistent are we when we criticize those 'others' when they say 'their' people received unfair trials, but when 'we' show that 'our' people did not have a fair trial, we expect everyone to believe us. In this specific case Busuladžić, like thousands of others, was put on trial and shot after the war. We need to look on that trial, as well as the judgment, from the perspective of the time when the process took place, in accordance with the laws and context of the moment the new government 
The media focused on the issue of Bosniak executions under communism in 2016, most particularly in the weekly Stav (The Attitude). This came at the time of the reburial of Bleiburg victims that were exhumed from the mass grave site of Huda Jama in Slovenia. ${ }^{31}$ It was then that certain individuals in Bosnia-Herzegovina began calling the Bleiburg death marches as the greatest tragedy in the history of Bosniaks. This was not only because of the existence of a large number of mass graves containing the bodies of Bosniaks, but also due to the fact that Bosniaks were members of different armed forces, as were many other nations in Yugoslavia, resulting in intra-ethnic as well as interethnic violence. ${ }^{32}$ Despite the fact that there is still a serious lack of research to confirm the exact national and religious denomination, as well as the total numbers, of all of the people killed in Bleiburg death marches, the calculations about the number of Bosniaks among them has grown into an important question. Even if all of Bosniak victims were to be detected, there would still be a problem in the accurate determination of their number because of their national identification and denomination at the time (most of them declared themselves as Croats). However, the media published different information on the number of victims, citing figures from 50,000 to 65,000 victims. ${ }^{33}$ When the remains exhumed from the site of Huda Jama were reburied, there were some nationalists who described the experience of Bosniaks at Bleiburg as a huge demographic disaster. ${ }^{34} \mathrm{At}$ the same time, significantly, there were no representatives of the BiH Islamic Community at the burial, and consequently, no graveside service (dženaza) was held for Bosniak victims from Huda Jama.

was being established and legitimated. From today's perspective we can say that the punishment was too harsh, but at the time when the trials were organized and the sentence carried out, it was the standard. I looked through several hundred judgments of individuals sentenced to death between 1945 and 1949 for acts they committed during the war. Many of them were accused of much milder crimes than those which were attributed to Busuladžić, but we never speak of those people. Why? How do we explain that we want to rehabilitate some, but not others? How do we justify Busuladžić's ties with the NDH, without justifying other aspects of the NDH? Should we pronounce everything to be false that does not fit with the image of Busuladžić we consider to be the proper one?", 12 April 2018, online at https://www.klix.ba/vijesti/bih/kamberovic-novepoliticke-elite-iniciraju-historijsku-reviziju-radi-vlastitog-legitimiteta.

31 Vijesti.ba, 7 March 2017, online at https://vijesti.ba/clanak/350811/huda-jama-uzasa-otkopano-1-420-zrtava-komunistickog-zlocina.

32 "Kad su antifašisti postali fašisti", Stav, 20 October 2016.

33 The mentioned figures related to the research by the Croatian historian Vedran Petrović. See Hamza Ridžal, "Partizani su u Hudoj Jami zakopali hiljade živih ljudi”, Stav, 27 October 2016.

34 Stav published an article on how Bosniaks suffered a demographic catastrophe on the Bleiburg death marches "Kako je Srebreničanin otkrivao Hudu Jamu", 31 October 2016, online at http://stav.ba/kako-je-srebrenicanin-otkrivao-hudu-jamu/. 
Within the Bosniak corpus, the prevalent political climate is also packed with nationalist content and battles for one's own historical truth, and there is an evident effort to create new interpretations of the Second World War, i.e. to compromise and deconstruct the antifascist culture of memory. This is reflected in the rhetoric and debates of the Bosniak national groups, which criticize the so-called leftists for being the proponents of politics that used to be, according to them, the most atrocious regime in $\mathrm{BiH}$, responsible for mass graves from Foča to Bleiburg, and whose political representatives still do not know how to deal with Bosnia or Islam, leading the country into crisis. ${ }^{35}$ However, the politics of memory of the Bosniak national parties is not entirely univocal nor consistent because, simultaneously, there are efforts to maintain the continuity of antifascism. For example, in Bosnia-Herzegovina 25 November is celebrated as Statehood Day, which is an acknowledgement of ZAVNOBiH (the State Anti-fascist Council for the National Liberation of BosniaHerzegovina) in the cultural memory, at least in the Federation Entity. Despite the fact that this date was acquired from the socialist holiday calendar and that Bosniak national circles take ideological positions that are different from the so-called leftist ideas, they are trying to assert this date as one of the foundations of the modern statehood of Bosnia-Herzegovina. The tenets of ZAVNOBiH, formulated in 1943, defined Bosnia-Herzegovina as a country that was equally Serbian, Muslim, and Croatian, and are very much topical and important today. ${ }^{36}$ Likewise, the literary award " $25^{\text {th }}$ November" can be examined in the same context. The weekly Stav, which is close to Bosniak nationalist circles, established this award. Not only does this underline the narrative about the continuity of the BiH statehood, but it also demonstrates how the new relationship towards the history of the Second World War is being adjusted and fabricated, and speaks of efforts to unify different interpretations, as well as traditional Islamic and antifascist values in the cultural memory of Bosniaks. ${ }^{37}$

\section{Conclusion}

More than twenty years after the end of the latest war, with the fresh memories of the tragic events of that time and the construction of different national collective memories about that conflict, painful questions from the Second World War are

35 "Džemaludin Latić: Dežulović započinje hajku na sve što u Bosni misli slobodoumno, izvan nadzora titoističkih špijunki”, 10 November 2015, online at http://thebosniatimes.ba/clanak/1829.

36 From the Resolution from the First Session of ZAVNOBiH.

37 This can be inferred from various speeches, symbolic gestures, and headlines such as "Both mahsus selam and Death to fascism". Filip Mursel Begović, "I mahsus selam i smrt fašizmu", Stav, 24 November 2016. 
still being raised in Bosnia-Herzegovina. In $\mathrm{BiH}$ society, there is a growing and openly expressed need to redefine and establish a new relationship towards the Second World War history. The public discourse, especially in the media, is filled with debates about fascism, antifascism, the issue of the selected past, and communist crimes. New positions are taken and new interpretations are given not only regarding the time of 1941-1945, but the entire socialist period in Yugoslavia. In a society torn by national divides, discussions about the difficult, and for a long time obscured and forgotten past, such as Bleiburg, mainly lack any serious historical approach. The public space is pervaded by new views, a revised relationship towards the Second World War, which is intertwined with the memories of the early 1990s. The victimization rhetoric of all three of the largest ethnic communities, especially their political leaders, exclusively focuses only on their own national victims. This rhetoric has the aim to strengthen the homogenization of their respective national groups, without any attempt to create an atmosphere of appreciation of "the other" or a critical approach to dealing with the past. In this way, the cultural memory of Bleiburg is being constructed using the established patterns of the national matrix, which paints a simplified picture of the tragic events. In the former Yugoslavia, politics of memory was built on selected events, primarily the People's Liberation War and the socialist revolution, and Yugoslav communists deliberately covered up events such as Bleiburg for ideological reasons. Today in Bosnia-Herzegovina, more than two decades after the collapse of Yugoslavia, we are still witnessing a reality where the politics of memory is being built without any responsibility or a critical view, from the perspective of only one's own national and historical truth. This only contributes to the atmosphere where Bosnian public space and society are left in a particular state, which is a consequence of what the essayist Ivan Lovrenović calls "an inappropriately buried past", the past that is constantly revived, thus significantly influencing the collective identities and narratives of all of us. ${ }^{38}$

38 Ivan Lovrenović, "Neupokojena prošlost i BiH”, 11 April 2011, online at http:/6yka.com/novost/8261/neupokojena-proslost-i-bih. 


\section{REFERENCES}

Assmann, Jan. 2005. Kulturno pamćenje. Vrijeme. Zenica.

Bergholz, Max. 2010. The Strange Silence: Explaining the Absence of Monuments for Muslim Civilians Killed in Bosnia during the Second World War. East European Politics and Societies, (24), 3.

Đerić, Gordana. 2009. Označeno i neoznačeno u narativima društvenog pamćenja: jugoslovenski slučaj, in: S. Bosto and T. Cipek (eds.): Kultura sjećanja 1945, povijesni lomovi i svladavanje prošlosti. Disput. Zagreb: 83-92.

Galić, Jure. 2005. Vrijeme i ljudi. Svjetlostkomerc. Sarajevo.

Halilbegović, Nihad, Hamzić, Omer and Spahić, Izet. 2015. Gračanlije u Marševima smrti 1945, iskazi preživjelih. Gračanički glasnik, 30: 81-104.

Hamzić, Omer. 2006. Oni su odstupili (Kako su 1945. doživjeli oni čiji su preci napostili BiH - na primjeru Gračanice), in: H. Kamberović (ed.): 60 godina od završetka Drugog svjetskog rata - kako se sjećati 1945. godine. Institut za istoriju. Sarajevo: 101-111.

Hasanbegović, Zlatko. 2007. Muslimani u Zagrebu 1878-1945: Doba utemeljenja. Ivo Pilar. Zagreb.

Haverić, Tarik. 2016. Kritika bosanskog uma - ogledi o jednom historijski fiksiranom mentalitetu. ECLD. Sarajevo.

Hoare, Marko Attila. 2006. Genocide and Resistance in Hitler's Bosnia: The Partisans and Chetniks 1941-1943. Oxford University Press. Oxford.

Hurem, Rasim. 2016. Bosna i Hercegovina u Drugom svjetskom ratu 1941.-1945. Plejada. Zagreb.

Jakiša, Miranda and Gilić, Nikica. 2015. Partisans in Yugoslavia: literature, film and visual culture. Transcript. Bielefeld.

Jambrešić-Kirin, Renata. 2006. Politička sjećanja na Drugi svjetski rat u doba medijske reprodukcije socijalističke kulture, in: L. Čale Feldman and I. Prica (eds.): Devijacije i promašaji: Etnografija domaćeg socijalizma. Institut za etnologiju i folkloristiku. Zagreb: 149-177.

Kamberović, Husnija. 2006. Novi pogledi na Drugi svjetski rat u BiH, in: H. Kamberović (ed.): 60 godina od završetka Drugog svjetskog rata-kako se sjećati 1945. godine. Institut za istoriju. Sarajevo: 25-35.

Karačić, Darko, Banjeglav, Tamara and Govedarica, Nataša. 2012. Re:vizija prošlosti: Politike sjećanja u Bosni i Hercegovini, Hrvatskoj i Srbiji od 1990. godine. Friedrich Ebert Stiftung. Sarajevo.

Kuljić, Todor. 2005. Integracija preko datuma. Helsinška povelja 87-89: 30-34.

Nora, Pierre. 1997. Realms of Memory. Columbia University Press. New York. 
Pavlaković, Vjeran. 2009. Komemorativna kultura Bleiburga 1990-2009, in: S. Bosto and T. Cipek (eds.): Kultura sjećanja 1945, povijesni lomovi i svladavanje prošlosti. Disput. Zagreb: 167-194.

Sulejmanpašić, Neđat. 2006. Od Sarajeva do Bleiburga i povratak, ratni dnevnik: 28. 12. 1944. - 11. 6. 1945. Medžlis islamske zajednice. Zagreb.

Sundhaussen, Holm. 2006. Jugoslavija i njene države sljednice. Konstrukcije, dekonstrukcije i nova konstrukcija sjećanja i mitova, in: M. Brkljačić and S. Prlenda (eds.): Kultura pamćenja i historija. Golden marketing - Tehnička knjiga. Zagreb: 239-289.

Amra Čusto is Research Associate at the Institute for the Protection of CulturalHistorical and Natural Heritage in Sarajevo.

Mailing Address: Amra Čusto, Kantonalni zavod za zaštitu kulturno-historijskog i prirodnog naslijeđa u Sarajevu, Josipa Štadlera 32, 71000 Sarajevo, Bosnia-Herzegovina.E-mail: amracusto@yahoo.com 